\title{
Selective Medium for Quantitative Detection and Observation of Propagules of Pythium zingiberum in Soil
}

\author{
Tokiya SHImizu* and Takio Ichitani** \\ 清水時哉*. 一谷多喜郎**:土鎄中に打けるPythium zingiberum \\ 繁殖体の定量および観察のための選択培地
}

Key Words : Selective medium, Pythium zingiberum, quantitative detection, observation, soil.

The soil dilution plate method has relatively low sensitivity for detecting Pythium zingiberum in soil ${ }^{1}$ and sometimes difficult to find its propagules. This paper deals with a new selective medium to improve sensitivity and to find the propagules more clearly. Part of the work has been reported elsewhere ${ }^{2}$.

The isolates of $P$. zingiberum UOP237, UOP252, UOP6656 causing rhizome rots of ginger and mioga ${ }^{3,4)}$ were mainly used. Both artificially (AI) and naturally infested (NI) soils were compared for quantitative detection and observation of propagules of this fungus. AI soil was prepared by mixing a known density of the propagules with $0.14 \%$ water agar containing sandy loam soil (autoclaved unless otherwise stated). NI soil was collected from the inside of plastic house where rhizome rot of ginger was unusually prevalent and kept in plant containers, either concrete cylinders or pots ${ }^{5}$. The medium of a routine dilution plate method ${ }^{6}$ was compared with the new medium regarding the propagules detected per gram oven dry soil (PPG) and/or their recovery percentages (R\%). Experiments were repeated at least twice.

Some experiments were performed in order to devise the new selective medium by reducing the amount of rose bengal in the routine medium ${ }^{6}$ and by adding antibiotics which has preliminarily confirmed to show any inhibitory effects on mycelial growth of P. zingiberum but toxic to soil bacteria. Results obtained from AI soil indicated that the sensitivity of detection increased slightly in a medium modified by reducing the rose bengal from 33 to 20ppm, increasing streptomycin (Meiji) from 40 to $100 \mathrm{ppm}$ and adding $100 \mathrm{ppm}$ vancomycin (Sigma). Similar results were obtained from NI soil. This

\footnotetext{
* Present address: Nagano Agricultural Experiment Station, Suzaka, Nagano 382, Japan 現在： 長野県農業試験場

** College of Agriculture, University of Osaka Prefecture, Sakai, Osaka 591, Japan 大阪府立大学 農学部

1) Ichitani, T., Tanaka, Y. and Tagami, Y. (1980). Ann. Phytopath. Soc. Japan $46: 86-87$ (Abstr.).

2) Shimizu, T. and Ichitani, T. (1983). Ibid. $49: 99$ (Abstr.). 3) Ichitani, T. and Shinsu, T. (1980). Ibid. $46:$ 435-441. 4) Ichitani, T. and Chikuo, Y. (1980). Ibid. 46:539-541. 5) Ichitani, T. and Shimizu, T. (1984). Bull. Univ. Osaka Pref., Ser. B $36: 15-19.6)$ Ichitani, T. (1981). Proc. Kansai Pl. Prot. Soc. $23: 60$ (Short com.).
} 
Starch-Peptone-Asparagine Medium

\begin{tabular}{|c|c|c|}
\hline $\mathrm{KH}_{2} \mathrm{PO}_{4}$ & 1.0 & \\
\hline $\mathrm{MgSO}_{4} \cdot 7 \mathrm{H}_{2} \mathrm{O}$ & 0.5 & \\
\hline peptone & 5.0 & g/ 1 distilled water, stored di 4 c \\
\hline L-asparagine & 0.27 & \\
\hline starch & 9.0 & \\
\hline
\end{tabular}

Selective medium for dilution plate method

- diluted the Starch-Peptone-Asparagine Medium to 32 times and supplemented with:

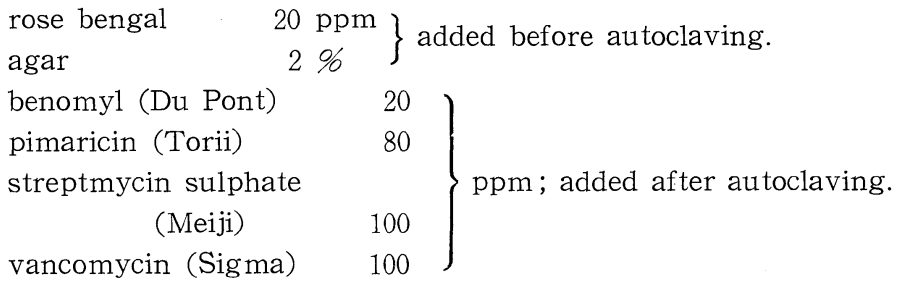

Fig. 1. Composition and preparation of the new selective medium.

Table 1. Comparative detection of Pythium zingiberum in artificially infested unautoclaved field soil by new selective medium under different incubation temperatures ${ }^{\text {a) }}$

\begin{tabular}{l|c|c|c}
\hline \multirow{2}{*}{ Selective medium } & Incubation & \multicolumn{2}{|c}{ Propagules/g oven dry soil } \\
\cline { 3 - 4 } & temperature (C) & Exp. 1 & Exp. 2 \\
\hline \multirow{2}{*}{ New selective medium } & 26 & 19.4 & 21.8 \\
& 30 & 48.4 & 72.6 \\
& 34 & 87.1 & 130.7 \\
Routine medium & 26 & - & 9.7 \\
& 30 & 7.3 & 26.6 \\
& 34 & 16.9 & 60.5 \\
\hline
\end{tabular}

a) Soil used was free from $P$. zingiberum. Inoculum density in Exp. $1: 2.5 \times 10^{5}$ hyphae mixed with $9.0 \times 10^{4}$ oospores/g oven dry soil. Inoculum density in

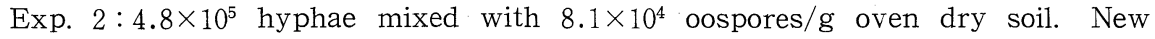
selective medium: see Fig. 1. - : Not detected.

modified medium was also shown to be superior to the routine medium for observing propagules in NI soil (Plate I) and for rapid identification ${ }^{7)}$. Amending this modified medium with amino acids or carbon sources previously selected for the mycelial growth of $P$. zingiberum, the dilution plate method was again applied for AI soil. Sensitivity was increased further, especially with L-asparagine or starch. Similar results were obtained from NI soil.

7) Shimizu, T. and Ichitani, T. (1982). Ann. Phytopath. Soc. Japan $48: 691-694$. 
From the above results, the new selective medium was devised (Fig. 1). With this medium, detective sensitivity of $P$. zingiberum increased in higher incubation temperature (Table 1), but the propagules in soil were easily detected only on the new medium at $34 \mathrm{C}$ (Plate II). This is probably due to high sensitivity of soil bacteria to the antibiotics at higher temperature. Moreover, incubation at $34 \mathrm{C}$, at which most Pythium spp. are unable to grow $^{8)}$, increase specificity of the present method for $P$. zingiberum. The best incubation time on the new medium was $24 \mathrm{hr}$ for both detection and observation of propagules.

The antibiotic "Agrimycin" (Daito Pfizer) gave poor results, probably due to the toxicity of oxytetracycline to $P$. zingiberum. Since this fungicide is easily obtainable and has been used for isolating other Pythium spp. from soi19-11), its application to $P$. zingiberum needs further study.

Sensitivity of the new medium increased about one order of magnitude over that of the routine medium (see Table 1 ). The lower limit of detection was estimated as $10^{2}$ PPG and R\% of propagules was calculated by the new medium at $34 \mathrm{C}$ as the values between 0.025 and 0.129 , equivalent to $10^{3}-10^{5} \mathrm{PPG}$ (see Table 1 ). The difference between the lower limit of detection and $\mathrm{R} \%$ is probably due to lower percentage (0.5-6.5 $\%$ ) of oospore germination of $P$. zingiberum on this medium. The uniform lower percentage of germination on several agar media, including the new one, may also indicate that there is at least no inhibitory action of the new medium on oospore germination of this fungus.

The new medium should be evaluated in ecological studies of $P$. zingiberum and the diseases it causes.

The authors are indebted to Prof. T. Inouye, University of Osaka Prefecture, and to Dr. D. J. Stamps, Commonwealth Mycological Institute, U.K., for their critical readings of the manuscript.

(Received December 19, 1983)

8) Middleton, J. T. (1943). Torrey Bot. Club Mem. $20: 1-171.99)$ Kageyama, K. and Ui, T. (1980). Ann. Phytopath. Soc. Japan $46: 542-544 . ~ 10)$ Kageyama, K. and Ui, T. (1981). Ibid. 47 : 313-319. 11) Kageyama, K. and Ui, T. (1982). Ibid. $48: 308-313$. 


\section{Explanation of plates}

\section{Plate I}

1-4. The medium modified by reducing the amount of rose bengal, increasing streptomycin, and adding vancomycin $(1,2)$ which was shown to be superior to the routine one $(3,4)$ for observing propagules in naturally infested soil.

$1,3:$ Filamentous sporangium-like structures

$$
\text { 2: oospore } \quad 4 \text { : undetermined }
$$

Arrows indicate the nature of propagules.

\section{Plate II}

1-6. The new selective medium which was easily detected the propagules at $34 \mathrm{C}$ in artificially infested unautoclaved field soil (3) as compared with the routine one (6). 1-3: Detected on the new selective medium.

4-6: Detected on the routine medium.
$1,4:$ Detected at $26 \mathrm{C}$
2,5: Detected at $30 \mathrm{C}$
3,6 : Detected at $34 \mathrm{C}$

\section{Plate I}

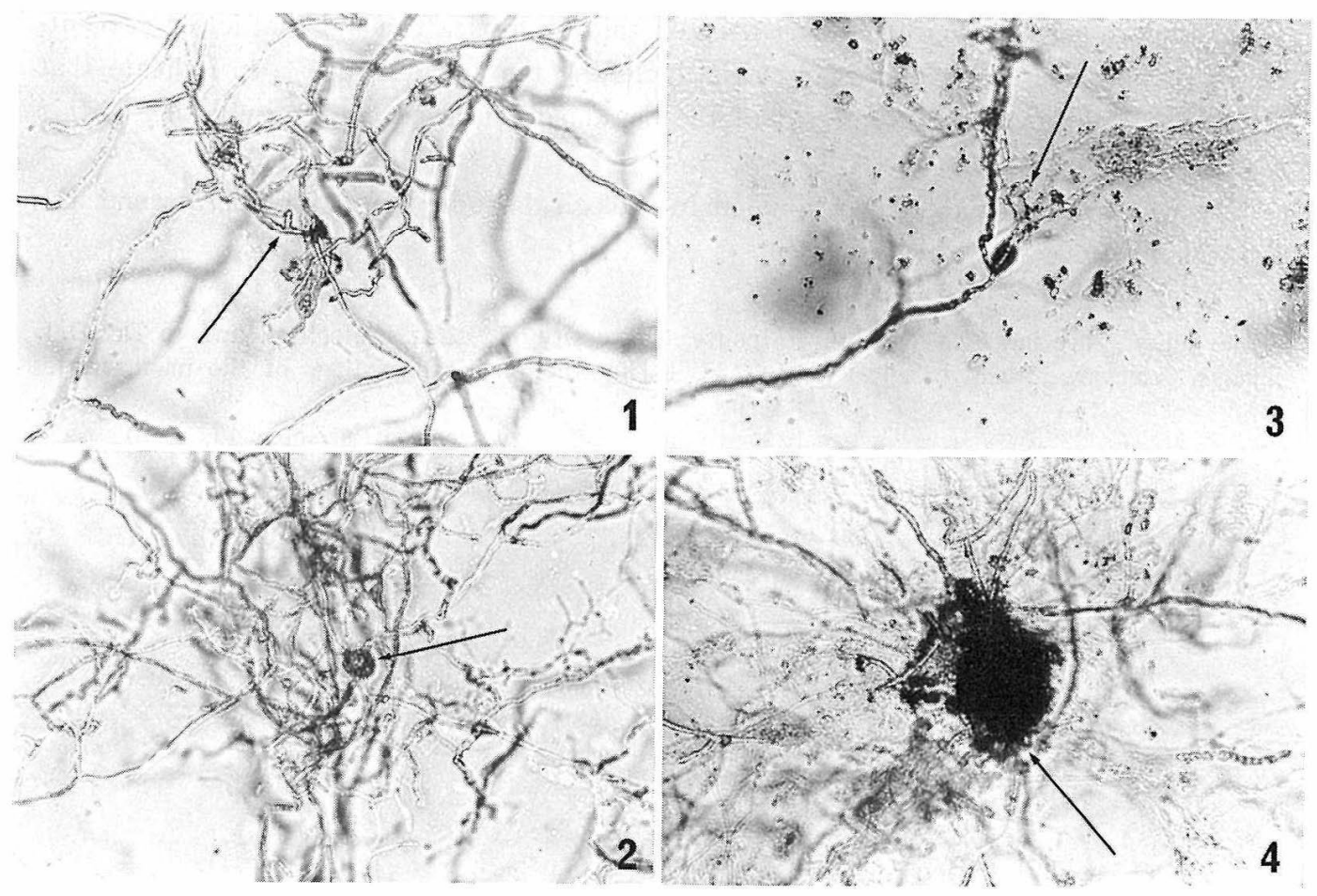


Plate II
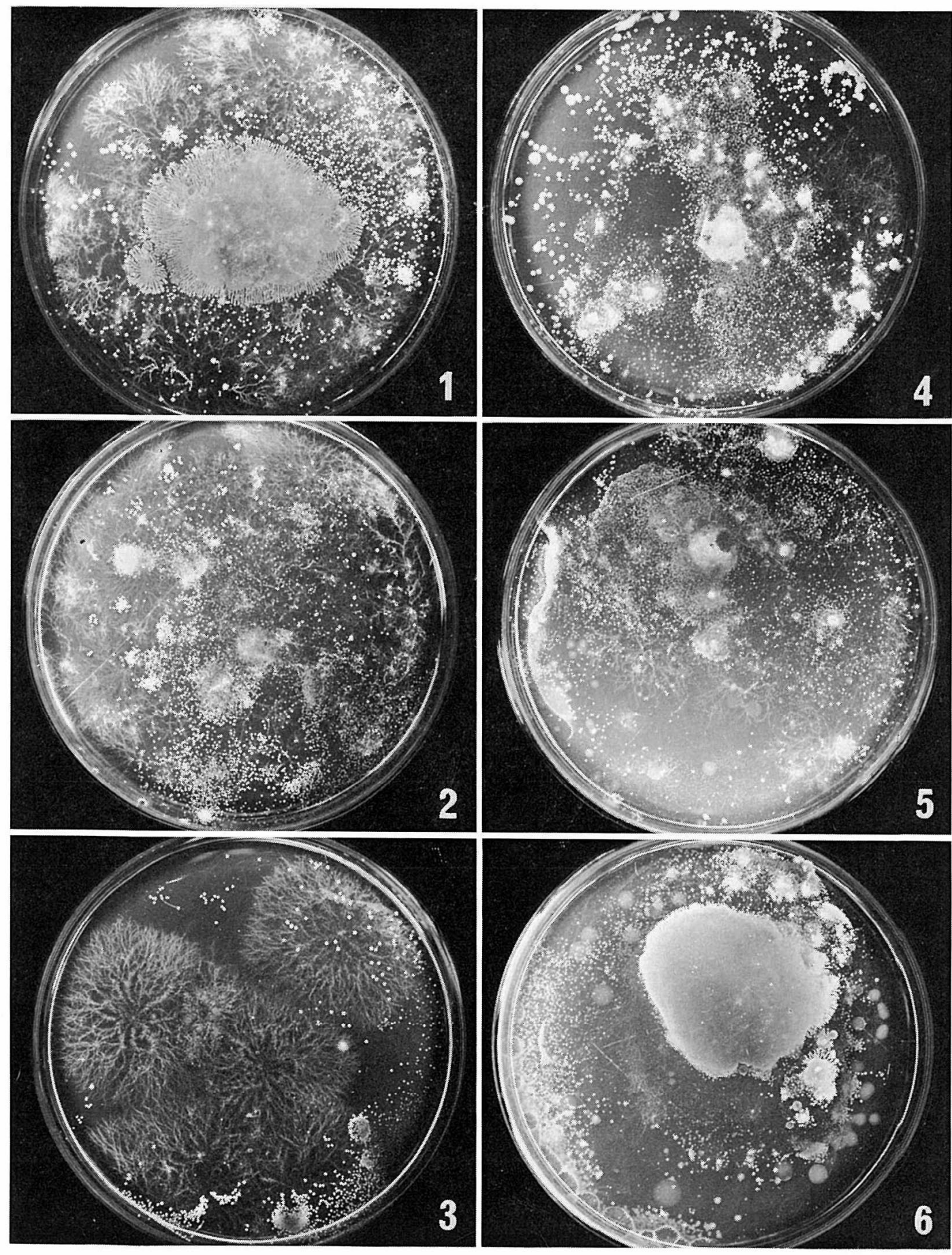